\title{
Evaluation of in vitro sucrase Inhibitory and non-enzymatic glycation properties of Ocimum tenuiflorum L. leaves
}

\author{
Antora, R.A., *Rabeta, M.S. and Norazatul Hanim, M.R. \\ Food Technology Division, School of Industrial Technology, Universiti Sains Malaysia, Minden, Gelugor \\ 11800, Penang, Malaysia
}

\author{
Article history: \\ Received: 11 March 2018 \\ Received in revised form: 18 \\ April 2018 \\ Accepted: 20 April 2018 \\ Available Online: 2 May \\ 2018
}

Keywords:

Sucrase,

Advanced glycation end products,

Non-enzymatic glycation,

Diabetes mellitus,

Hyperglycemia

DOI:

https://doi.org/10.26656/fr.2017.2(4).076

\begin{abstract}
Different concentrations of aqueous and ethanolic extracts of Ocimum tenuiflorum L. leaves were evaluated for their sucrase inhibition and non-enzymatic glycation inhibitory effects. The results revealed that aqueous extracts, particularly the one from oven-dried leaves had significant inhibition potential for all three assays. The $\mathrm{IC}_{50}$ values for sucrase inhibition assay, BSA-glucose assay, and BSA-fructose assay were, $370.48 \pm 2.14 \mu \mathrm{g} / \mathrm{ml}$, $188.19 \pm 2.52 \mu \mathrm{g} / \mathrm{ml}$, and $166.16 \pm 1.99 \mu \mathrm{g} / \mathrm{ml}$, respectively and the highest inhibition found in $1250 \mu \mathrm{g} / \mathrm{ml}$ were, $91.88 \pm 0.16 \%, 118.46 \pm 0.27 \%$, and $104.15 \pm 0.21 \%$, respectively. Other than that, the aqueous extract of fresh leaves and $50 \%$ ethanol extract of oven dried leaves also showed good inhibition activity. Though, the results presented the highest inhibition activity for BSA-glucose assay. The leaves also attained 50\% inhibition with the lowest concentration for BSA-fructose assay. The overall result of $O$. tenuiflorum leaves suggested that it can be used for treating diabetes mellitus and the complications associated with this.
\end{abstract}

\section{Introduction}

Diabetes mellitus (DM) and its complications are increasing with time in every part of the world (Tupe et al., 2017). It is a metabolic disorder characterized by increased blood glucose level because of insulin production deficient or defects in insulin action, sometimes both (Singh et al., 2016). With the onset of type IIDM it links with hyperglycemia, an unusual elevation of postprandial blood glucose level (Li et al., 2014). It is crucial to control in the postprandial hyperglycemia in the early treatment of DM as it can cause different health complications (Ahmed et al., 2009; Hu et al., 2013). Different carbohydrate hydrolyzing enzymes such as $\alpha$-amylase, $\alpha$-glucosidase, and sucrase in the small intestine can reduce the absorption of glucose level and thus, postprandial hyperglycemia (Rhabasa-Lhoret and Chiasson, 2004). The postprandial hyperglycemia can be reduced by inhibiting the activity of carbohydrate hydrolyzing enzymes in the brush border of the small intestine. This will slow down the process of carbohydrate digestion and absorption. Hence, the rate of glucose absorption will be delayed. As a result, postprandial plasma glucose rise will be hindered (Mohamed et al., 2012).

Prolonged hyperglycemia leads to failure and damage to multiple organs and develops secondary complications in diabetic patients (Kaewnarin and Rakariyatham, 2017). Acute complications can cause lipid and protein metabolic mutation and more persistent complications such as retinopathy, cataracts, atherosclerosis, neuropathy, aging and many more (Pashikanti et al., 2010). The major reason for these complications is Advanced Glycation End Products (AGEs). The non-enzymatic glycation of protein and is an elementary cause of these secondary complications (Brownlee, 2001). Non-enzymatic protein glycation is occurred by the reaction between the carbonyl group of reducing sugars (glucose, fructose, and ribose) and the amino group of proteins. This is also known as Maillard reaction (Kaewnarin and Rakariyatham, 2017). A Schiff base is formed during the early stage which afterward rearranged through oxidative pathways to make more stable Amadori products (Brownlee, 2001). These amadori products go through different complicated reactions (dehydration, oxidation, cyclisation) and several highly Reactive Carbonyl Species (RCS) are formed. These reactive carbonyl compounds such as glyoxal, methylglyoxal (MGO) and 3-deoxy-glucosone react with amino groups of both extra-cellular and intracellular protein that forms fluorescent and nonfluorescent AGEs (Cervantes-Laurean et al., 2006; Deve 
et al., 2014). The AGEs develop cross-links with longlived proteins like collagens and alters their function (Hsieh et al., 2007).

Inhibition of both the carbohydrate hydrolyzing enzyme and AGEs are greatly needed to avoid the early and the secondary complications induced by hyperglycemia (Peng, Zheng, Cheng et al., 2008; Hu et al., 2013). There are some popular inhibitors like acarbose, miglitol, and voglibose to inhibit the carbohydrate hydrolyzing enzymes like sucrase (Bailey, 2003). Acarbose has been used in treating the diabetic patients in recent times. It can also reduce complications like retinopathy and neuropathy but synthetic acarbose are often reported to cause gastrointestinal side effects as it can induce abdominal pain, flatulence or diarrhoea because of the bacterial fermentation of undigested carbohydrate in the colon (Derosa and Maffiloli, 2012; He et al., 2014). Similarly, many synthetic drugs, for example, aminoguanidine, aspirin, taurine, vitamin B6 and quercetin have been reported in many research to reduce non-enzymatic glycation. Among all these drugs, aminoguanidine was reported as a specific inhibitor of AGE formation, cross-linking of protein and it can also inhibit accelerated diabetic retinopathy (Matsuura et al., 2002). The disadvantage of using these drugs is, a very high dose required for the inhibition of which lead to various side effects including toxicity (Pripdeevech et al., 2010).

The side effects of these synthetic drugs have lead researchers to look for natural alternatives. To treat the non-communicable chronic diseases, traditional and complementary medicines like herbal therapies are becoming popular with time (Tupe et al., 2015). A recent concern has been arising is the use the bioactive compounds from plants to inhibit the formation of AGEs as well as reduce the activity of carbohydrate hydrolyzing enzymes (Peng, Cheng, Ma et al., 2008). Different species of the genus Ocimum have shown strong effects such as antioxidant, anti-stress, antimicrobial, anticancer, antidiabetic and so many (Bano et al., 2017). The species O. tenuiflorum, as well as the other species of Ocimum (Ocimum basillicum, Ocimum americanum, Ocimum gratissimum), have been known for reducing the blood glucose level. It has been used as a remedy for DM and high cholesterol since ancient times (Kaewnarin and Rakariyatham, 2017). The reports of significant antioxidant property of this plant have made it a potential natural source to inhibit the AGEs because oxidation stress in hyperglycemia induces free radicals by glucose auto-oxidation and interruption of electron transport chain with also assists in the formation of AGEs (Naowaboot et al., 2009; Nahak et al., 2011; Deo et al., 2013). As for the inhibitory property of $O$. tenuiflorum against the non-enzymatic glycation, this area still has a lot to explore. There are only a few works that have been done on this property of the plant as well as its sucrase inhibitory effect.

This research mainly focuses on the carbohydrate hydrolyzing enzyme inhibitory and non-enzymatic glycation inhibitory properties of different extracts of $O$. tenuiflorum leaves by surase inhibition assay and BSAglucose and BSA-fructose assay.

\section{Materials and methods}

\subsection{Plant materials}

Fresh O. tenuiflorum plants were collected from Kuala Kurau, Perak. The authentication of the leaves was done at Universiti Sains Malaysia (voucher specimen number 11400). Leaves with no physical damages and proper maturity were chosen as sample.

\subsection{Sample preparation and extraction}

The fresh leaves from the O. tenuiflorum plants $(2.6$ $\mathrm{kg}$ ) were separated and washed thoroughly with water to remove any dust particles or other foreign materials. Then, the extra water on the leaf surface was removed by drying in open air at room temperature of $28^{\circ} \mathrm{C}$. The leaves were divided into two equal batches. One batch of the leaves was dried in the oven overnight at $55^{\circ} \mathrm{C}$ and then pulverized and prepared for solvent extraction (Hannan et al., 2006; Basu et al., 2013). Both the raw and oven-dried leaves were extracted with water and different strengths of ethanol $(50 \%, 75 \%$, and $100 \%)$ were used. For water extraction, the oven-dried and raw leaves were soaked in water overnight at room temperature $\left(28^{\circ} \mathrm{C}\right)$. Then, the supernatant was collected and centrifuged at $3000 \mathrm{rpm}$ to remove any remaining solid particle. The final supernatant was collected and freeze-dried to make lyophilized powder. For the ethanol extraction, both raw and oven-dried leaves were soaked in different strengths of ethanol for 48 hours. Then, the extracts were filtered, and the filtrates were kept in a water bath at $60^{\circ} \mathrm{C}$ for three days to remove the excess amount of solvent and obtained the desired samples. All the samples were stored in the refrigerator for future use.

\subsection{Analysis of antihyperglycemic activity}

\subsubsection{Sucrase inhibition assay}

Inhibitory effect of sucrase was determined with slight modifications of the method of a previous study (Ahmed et al., 2009). Enzyme (sucrase), sucrose and different concentration of sample solutions $(250 \mu \mathrm{g} / \mathrm{ml}$, $500 \mu \mathrm{g} / \mathrm{ml}, 750 \mu \mathrm{g} / \mathrm{ml}, 1000 \mu \mathrm{g} / \mathrm{ml}, 1250 \mu \mathrm{g} / \mathrm{ml}$ ), respectively were prepared using Phosphate Buffer 
Saline (PBS). The enzyme solution of $10 \mu 1$ and varying concentration of samples were placed in glass test tubes followed by incubation at $37^{\circ} \mathrm{C}$ for $10 \mathrm{~min}$. After that, the volume was made up to $200 \mu \mathrm{l}$ by malate buffer ( $\mathrm{pH}$ 6.0) and $100 \mu 1$ of $60 \mathrm{mM}$ sucrose was added to the tube. The tubes were again left for incubation at $37^{\circ} \mathrm{C}$ for another $30 \mathrm{~min}$. After completing the incubation $200 \mu \mathrm{l}$ of DNS reagent was added to each tube. The reaction was terminated by putting the tubes in boiling water bath for $10 \mathrm{~min}$. The absorbance of the samples was read at $\mathrm{UV}-\mathrm{V}$ is spectrophotometer at a wavelength of $540 \mathrm{~nm}$. Inhibition of sucrase was calculated according to the following formula:

$$
\% \text { Inhibition }=\frac{\text { Absorbance of control-Absorbance of sample }}{\text { Absorbance of control }} \times 100
$$

\subsubsection{Non-enzymatic glycation assay by BSA-glucose} model

Antiglycation assay had been done to measure the percent of inhibition of Advanced Glycation End (AGE) products. In all experiments, the final reaction volume was $1 \mathrm{ml}$ and the reactions were performed in $1.5 \mathrm{ml}$ micro-centrifuge tubes. A $500 \mu 1$ of BSA $(1 \mathrm{mg} / \mathrm{ml})$ was incubated with $400 \mu \mathrm{l}$ of glucose $(400 \mathrm{mM})$ in the presence of $100 \mu \mathrm{l}$ of different concentration of extracts $(250 \mu \mathrm{g} / \mathrm{ml}, 500 \mu \mathrm{g} / \mathrm{ml}, 750 \mu \mathrm{g} / \mathrm{ml}, 1000 \mu \mathrm{g} / \mathrm{ml}, 1250$ $\mu \mathrm{g} / \mathrm{ml}$ ), arbutin (positive control), or PBS as the control buffer at the specified concentration. The reaction could proceed at $60^{\circ} \mathrm{C}$ for $24 \mathrm{~h}$. The reaction mixture was allowed to cool at room temperature, and the reaction was stopped by adding $10 \mu \mathrm{l}$ of $100 \% \quad(\mathrm{w} / \mathrm{v})$ trichloroacetic acid (TCA). The TCA-added mixture was kept at $4^{\circ} \mathrm{C}$ for 10 min before centrifugation at 13000 $\mathrm{rpm}$. The precipitate was redissolved with $4 \mathrm{ml}$ PBS (pH 7.2), and the relative amount of glycated bovine serum albumin (BSA) was immediately determined based on fluorescence intensity by use of a cary-eclipse spectrofluorometer. The excitation and emission wavelengths used were at 370 and $440 \mathrm{~nm}$, respectively (Chen et al., 2011). Results were expressed as percentage inhibition of formation of the glycated protein. Inhibition of AGE's was analysed according to the formula:

$\%$ Inhibition $=\left[1-\left(\frac{\text { Fluoroscence of sample }- \text { Fthe luoroscence of sample negative }}{\text { fluoroscenceofcontrol }- \text { fluoroscenceofcontrol blank }}\right)\right] \times 100$

\subsubsection{Non-enzymatic glycation assay by BSA- fructose model}

The assay was done with slight modifications of a previous study (Meenatchi et al., 2017) which was also like non-enzymatic glycation by BSA-glucose model. Just for the incubation of BSA, approximately $400 \mu \mathrm{l}$ of fructose $(400 \mathrm{mM})$ was used instead of glucose. The relative amount of glycated bovine serum albumin (BSA) was determined based on fluorescence intensity by use of a cary-eclipse spectrofluorometer. The excitation and emission wavelengths used were at 370 and $440 \mathrm{~nm}$, respectively. Results were expressed as percentage inhibition of formation of the glycated protein. Inhibition of AGE's was analysed according to the formula:

$\%$ Inhibition $=\left[1-\left(\frac{\text { Fluoroscence of sample-Fluoroscence of sample negative }}{\text { fluoroscenceofcontrol-fluoroscenceofcontrol blank }}\right)\right] \times 100$

\subsubsection{Statistical analysis}

Each experiment was performed in triplicate for every concentration of all the samples. The data were expressed as mean $\pm \mathrm{SD}$ (Standard Deviation of the mean). Statistical analysis was performed for ANOVA (analysis of variance) followed by Duncan's test with SPSS version 20.0. Values of $p \leq 0.05$ were considered as significant.

\section{Results}

Eight different extracts of Ocimum tenuiflorum L. leaves were evaluated for its inhibitory properties by sucrase inhibition assay and non-enzymatic glycation (BSA-glucose and BSA-fructose model) assay. The aqueous and the three different ethanol extracts of both fresh and oven-dried leaves Ethanol:water (50:50), Ethanol:water (75:25) and Ethanol:water (100:0) were prepared in five different concentration: $250 \mu \mathrm{g} / \mathrm{ml} ; 500$ $\mu \mathrm{g} / \mathrm{ml} ; 750 \mu \mathrm{g} / \mathrm{ml} ; 1000 \mu \mathrm{g} / \mathrm{ml}$; and $1250 \mu \mathrm{g} / \mathrm{ml}$. The best sample had been selected by their ability of inhibition in all three assays.

\subsection{Sucrase inhibition assay}

The inhibition of sucrase by different concentrations of sample extracts is presented in Figure 1. According to the result, the oven-dried aqueous leaf extract of 1250 $\mu \mathrm{g} / \mathrm{ml}$ showed the strongest inhibitory effect against sucrase which is $91.88 \pm 0.16 \%$. Followed by, fresh aqueous leaf extract of same concentration and ovendried aqueous leaf extract of $1000 \mu \mathrm{g} / \mathrm{ml}$, which were respectively $84.44 \pm 0.03 \%$ and $81.30 \pm 0.04 \%$. The percentages were higher than that of the reference standard acarbose which was $82.58 \pm 0.07$ and $75.06 \pm 0.00$, respectively. The oven-dried aqueous leaf extract had demonstrated better result than the other extracts for all concentrations. Among all extracts, the $100 \%$ ethanol extract of oven-dried leaves had shown a minimum percentage of inhibition compared to the other extracts. The highest percentage of inhibition was $65.64 \pm 0.00 \%$ for $1250 \mu \mathrm{g} / \mathrm{ml}$, and the lowest was $19.23 \pm 0.64 \%$ for $250 \mu \mathrm{g} / \mathrm{ml}$, which were much lower than both acarbose and oven-dried aqueous leaves. All the sample extracts had shown a gradual increase in the inhibition with their concentration except for the concentration of $750 \mu \mathrm{g} / \mathrm{ml}$ and $1000 \mu \mathrm{g} / \mathrm{ml}$ which had 


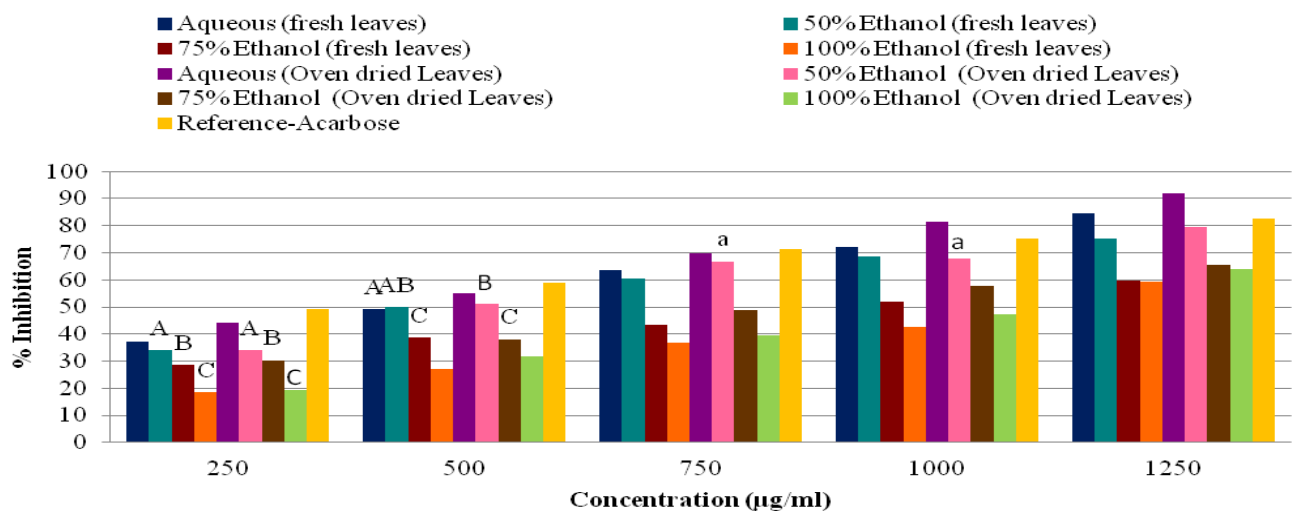

Figure 1. Sucrase inhibition assay. Values are expressed as mean \pm SD. Values followed by same capital letters in same concentration had no significant difference and values followed by same small letters in different concentration had no significant difference.

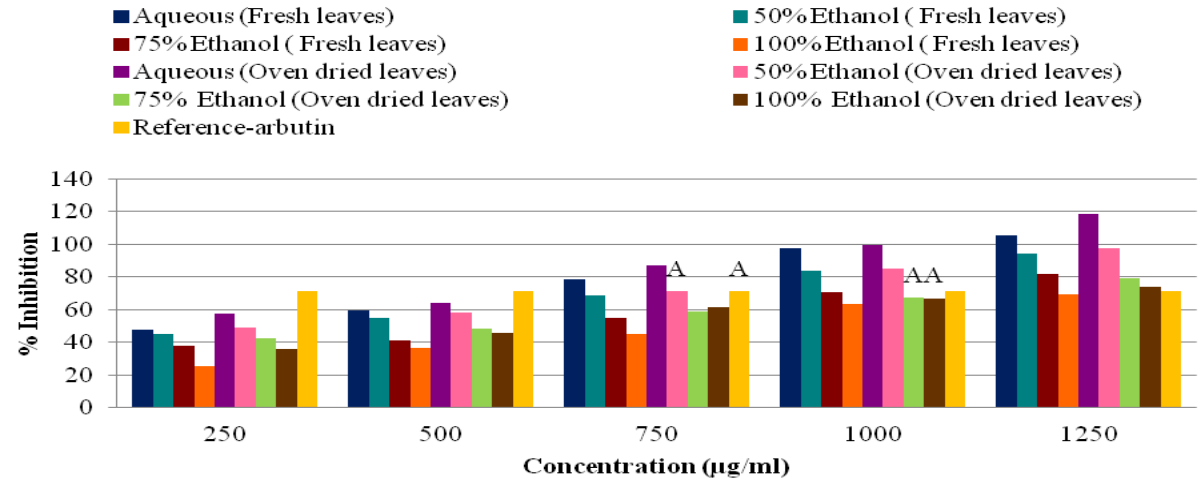

Figure 2. Non-enzymatic glycation by BSA-glucose model. Values are expressed as mean \pm SD. Values followed by same letters in same concentration have no significant difference.

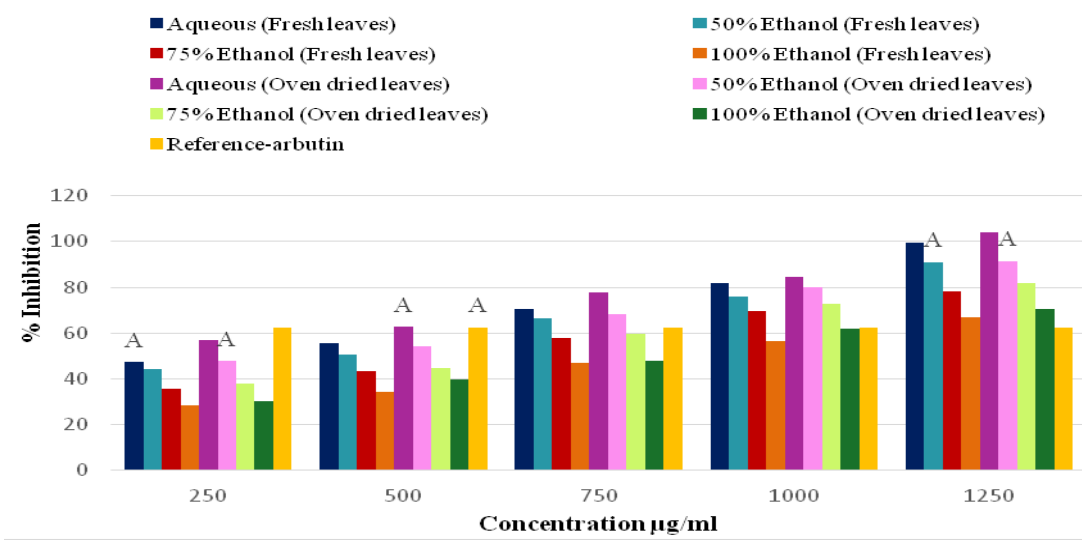

Figure 3. Non-enzymatic glycation by BSA-fructose model. Values are expressed as mean $\pm \mathrm{SD}$. Values followed by same letters in same concentration have no significant difference.

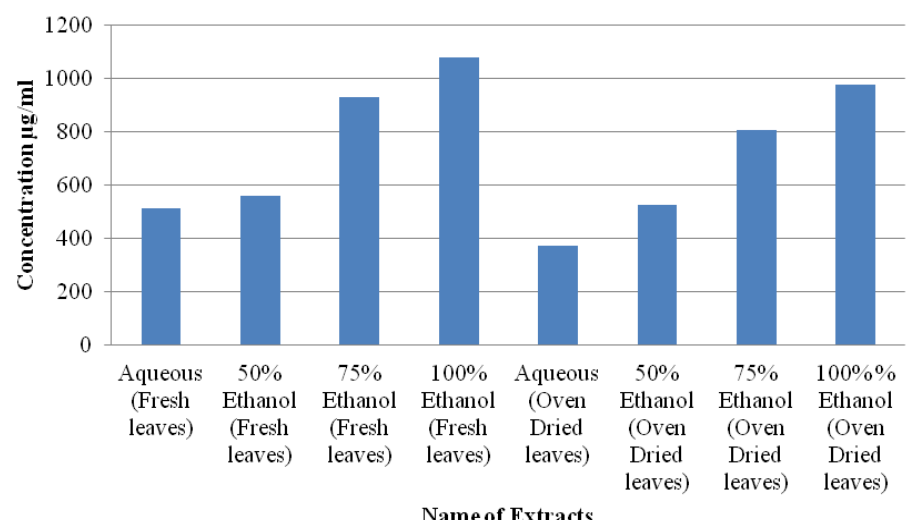

Figure $4 . \mathrm{IC}_{50}$ values for sucrase inhibition assay. Values are expressed as mean $\pm \mathrm{SD}$.

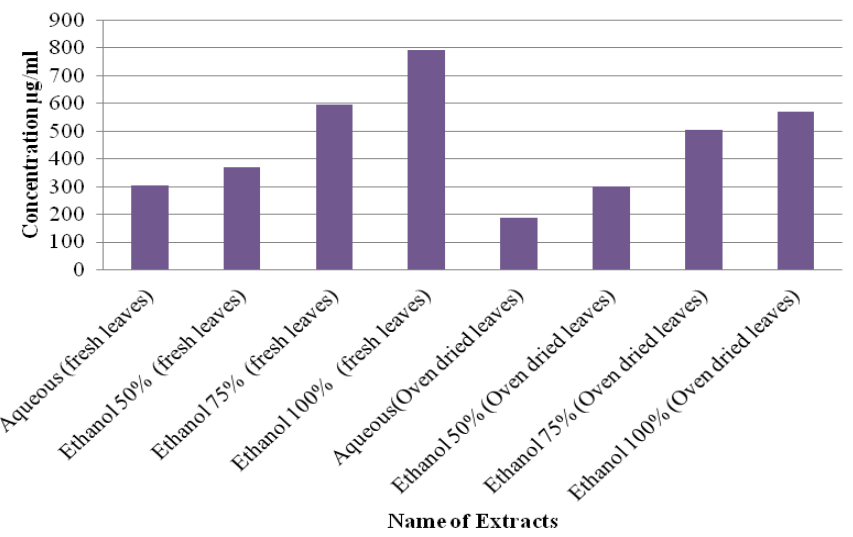

Figure 5. $\mathrm{IC}_{50}$ values for Non- enzymatic glycation assay by BSA-glucose model. Values are expressed as mean \pm SD. 
no significant differences $(\mathrm{p}>0.05)$. The highest inhibition percentage for $50 \%, 75 \%$ and $100 \%$ ethanolic oven-dried leaf extracts were $79.67 \pm 0.00 \%$, $65.64 \pm 0.00 \%$ and $63.91 \pm 0.06 \%$ respectively, in $1250 \mu \mathrm{g} /$ $\mathrm{ml}$. For fresh leaves, the results were $75.06 \pm 0.00 \%$, $59.70 \pm 0.13 \%$, and $59.38 \pm 0.04 \%$, respectively for the same concentration. All the samples exhibited low percentage of inhibition for the concentration of $250 \mu \mathrm{g} /$ $\mathrm{ml}$ for both oven-dried and fresh leaves, as $50 \%$ and $75 \%$ ethanolic extracts had inhibition of $33.97 \pm 1.2 \%$, $30.34 \pm 0.37 \%, \quad 33.97 \pm 0.64 \% \quad$ and $28.63 \pm 0.98 \%$, respectively. Though there are significant differences in all the samples, some samples had shown similar inhibitory potentials. For $250 \mu \mathrm{g} / \mathrm{ml}$ concentration, all the ethanol extracts for both fresh and oven-dried leaves had no significant differences $(\mathrm{p}>0.05)$ in their inhibitory potential. The $\mathrm{IC}_{50}$ value for oven-dried aqueous leaves was $370.48 \pm 2.14 \mu \mathrm{g} / \mathrm{ml}$ (Figure 4). Furthermore, for fresh aqueous leaf extracts, it was $511.50 \pm 0.50 \mu \mathrm{g} / \mathrm{ml}$. For fresh leaves with $50 \%, 75 \%$ and $100 \%$ ethanolic extracts the $\mathrm{IC}_{50}$ values were $561.48 \pm 7.22 \mu \mathrm{g} / \mathrm{ml}$, $928.33 \pm 9.82 \mu \mathrm{g} / \mathrm{ml}, 1080.95 \pm 6.45 \mu \mathrm{g} / \mathrm{ml}$, respectively and for oven-dried $50 \%, 75 \%$ and $100 \%$ ethanolic leaf extracts, $524.95 \pm 12.69 \mu \mathrm{g} / \mathrm{ml}, 808.57 \pm 13.21 \mu \mathrm{g} / \mathrm{ml}$ and $927.96 \pm 8.45 \mu \mathrm{g} / \mathrm{ml}$ respectively.

\subsection{Non-enzymatic glycation assay by BSA-glucose model}

Figure 2 represents the results for inhibition of AGEs by non-enzymatic glycation. BSA-glucose model was used for this assay and the results showed the inhibition percentages of the glycated protein of different $O$. tenuiflorum leaf extracts. The aqueous extracts of ovendried leaves were found to have the strongest inhibitory effect against AGEs with $118.46 \pm 0.27 \%$ for $1250 \mu \mathrm{g} / \mathrm{ml}$. For the aqueous extract of fresh leaves, the inhibition was $105.45 \pm 0.40 \%$ for the same concentration. All sample extracts had a stronger inhibitory effect on AGEs in $1250 \mu \mathrm{g} / \mathrm{ml}$ concentration than the reference standard arbutin, which was found to be $71.29 \pm 0.00 \%$ for all concentrations of sample extracts. Arbutin is a wellknown drug with good antiglycation properties and used by other researchers in previous studies (Perera et al., 2014). For $1000 \mu \mathrm{g} / \mathrm{ml}$, only the aqueous and $50 \%$ ethanolic extract of both fresh and oven-dried leaves had better inhibition than arbutin which were $97.71 \pm 0.15 \%$, $99.20 \pm 0.26 \%, \quad 83.55 \pm 0.40 \% \quad$ and $84.96 \pm 0.26 \%$, respectively. Other than that, aqueous leaf extracts of $750 \mu \mathrm{g} / \mathrm{ml}$ of both fresh and oven-dried leaves had demonstrated better inhibitory properties than arbutin which were $78.18 \pm 0.40 \%$ and $87.07 \pm 0.26 \%$, respectively. The $250 \mu \mathrm{g} / \mathrm{ml}$ and $500 \mu \mathrm{g} / \mathrm{ml}$ concentrations for all the sample extracts had lower inhibition percentages than the reference standard. All the samples had a continuous increase in the inhibition with the increase in concentration. Among all the samples, the oven-dried aqueous leaves had the best effect on inhibiting AGEs with an $\mathrm{IC}_{50}$ value (Figure 5) of $188.19 \pm 2.52 \mu \mathrm{g} / \mathrm{ml}$ which was lower than all the other samples. It could mean that it can obtain 50\% inhibition at the lowest concentration. The aqueous extract with fresh leaves had an $\mathrm{IC}_{50}$ value of $302.66 \pm 1.25 \mu \mathrm{g} / \mathrm{ml}$. All the ethanolic extracts had higher $\mathrm{IC}_{50}$ values than both the aqueous extract except $50 \%$ ethanol extract of ovendried leaves which is lower than fresh aqueous leaf extract with $300.65 \pm 3.16 \mu \mathrm{g} / \mathrm{ml}$. Though, all the results clearly showed that $50 \%$ inhibition can be obtained with much lower concentration than $1250 \mu \mathrm{g} / \mathrm{ml}$.

\subsection{Non-enzymatic glycation assay by BSA-Fructose}

The results for non-enzymatic glycation by BSAfructose model is presented in Figure 3. The figure shows the inhibition properties of all the sample extracts. The reference standard had also been evaluated with arbutin. In accordance with the other two assays, ovendried aqueous leaves extract had exhibited the strongest potential for inhibiting glycated protein. The highest inhibition of oven-dried aqueous leaves was $104.15 \pm 0.21 \%$ for $1250 \mu \mathrm{g} / \mathrm{ml}$ and it was $57.10 \pm 0.32 \%$ for $250 \mu \mathrm{g} / \mathrm{ml}$. The results were better than all other sample extracts for the same concentration. Other than this, the fresh leaves aqueous extract and 50\% ethanolic extracts for both fresh and oven-dried leaves showed fair percentages of inhibition. All the samples, except 100\% ethanol extract of fresh leaves for $1250 \mu \mathrm{g} / \mathrm{ml}$, showed better inhibitory potential than arbutin which was $69.53 \pm 0.00 \%$. For both the $100 \%$ ethanol extracts, the results were comparatively poor than the other samples. As well as the BSA-glucose model, a decrease in the inhibitory property had been observed with increasing amount of ethanol. There also had been an increase in inhibition with increasing concentrations in the entire sample. But, for some sample concentrations, no significant difference $(p>0.05)$ was observed in the inhibition. For example, aqueous extract of fresh leaves and $50 \%$ ethanol extract of oven-dried leaves showed a similar percentage of inhibition at $250 \mu \mathrm{g} / \mathrm{ml}$. The $75 \%$ ethanolic extract of fresh leaves had similar inhibition potential as arbutin with $69.78 \pm 0.32 \%$ of inhibition. For $250 \mu \mathrm{g} / \mathrm{ml}$ and $500 \mu \mathrm{g} / \mathrm{ml}$, all the samples had lower inhibition percentage than arbutin. The $\mathrm{IC}_{50}$ values for this assay have been also presented in Figure 6. In Figure 6 , the $\mathrm{IC}_{50}$ value for oven-dried aqueous leaves extract is $163.16 \pm 1.99 \mu \mathrm{g} / \mathrm{ml}$ which is much lower than the lowest selected concentration $250 \mu \mathrm{g} / \mathrm{ml}$. The $\mathrm{IC}_{50}$ value for aqueous extracts of fresh leaves was $350.23 \pm 3.66 \mu \mathrm{g} / \mathrm{ml}$ which is nearly similar to $50 \%$ ethanol extract of ovendried leaves value for $\mathrm{IC}_{50}$ of $345.90 \pm 11$. The highest 
$\mathrm{IC}_{50}$ value is for $100 \%$ ethanolic extract of fresh leaves which is $833.34 \pm 4.83 \mu \mathrm{g} / \mathrm{ml}$ which also had the lowest inhibition percentage. Observing the $\mathrm{IC}_{50}$ values it can be said that, all the samples attained 50\% inhibition level with much lower concentration than the highest one used for this assay especially, oven-dried aqueous leaves extract.

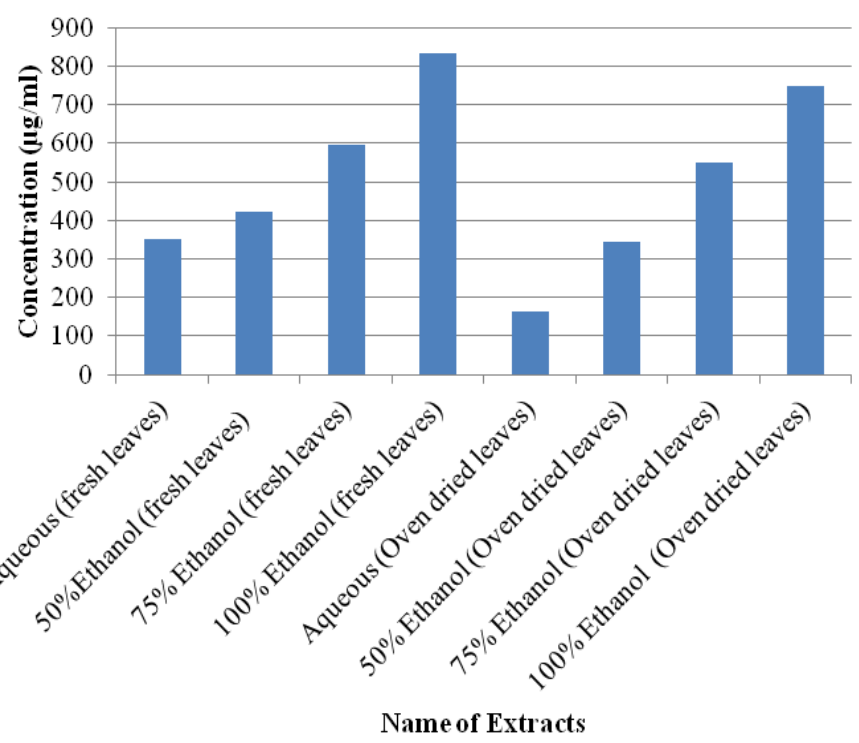

Figure $6 . \mathrm{IC}_{50}$ values for Non- enzymatic glycation assay by BSA-fructose model. Values are expressed as mean $\pm \mathrm{SD}$.

All these three assays which were performed to evaluate the different extracts of $O$. tenuiflorum leaves had reported that aqueous extract of both oven-dried and fresh leaves had strong potential to contribute in reducing both early and secondary complications in type two DM followed by $50 \%$ ethanolic extract of ovendried leaves and fresh leaves respectively. The other extracts had moderate inhibition percentages compared with these.

\section{Discussion}

The antioxidant potential of $O$. tenuiflorum plants had played the key role in its antihyperglycemic activities. The antioxidant properties of a plant depend on the amount of different phenolic components present in it (Inampudi et al., 2010). There are several reports that suggested that phenolic compounds have antidiabetic activities (Gandhi et al., 2011; Abdallah et al., 2011; You et al., 2012; $\mathrm{Hu}$ et al., 2013). O. tenuiflorum plants had been recognised for their strong antioxidant effects as they had proved their potential in both in-vitro and in-vivo studies (Kath and Gupta, 2006). Therefore, it can be assumed that this property had likely been contributed towards its sucrase and AGE inhibition in this study.

Sucrase is one of the key enzymes in brush borders of the small intestine which involves in starch breakdown and intestinal glucose absorption. These enzymes catalyze the hydrolysis of sucrose to glucose and fructose. Inhibition of sucrase can reduce the rate of glucose absorption in the blood (Li et al., 2014). Both aqueous extracts of leaves showed stronger inhibitory properties than other against sucrase. This inhibitory property could be related to their total phenolic components. Aqueous extract of $O$. tenuiflorum leaves had been reported to have a high amount of phenolic components than hexane, chloroform, ethyl acetate and methanol extracts (Shetty et al., 2008; Mahomoodally et al., 2012; Mousavi et al., 2016).The presence of these phenolic compounds such as eugenols, rosmarinic acids, luteolin, apigenin, glucosides, saponins etc. could be thought as the possible reason for their sucrase inhibitory property (Singab et al., 2014; Verma, 2016; Kaewnarin and Rakariyatham, 2017). Among these, eugenol had been used for reducing glucose metabolism (Srinivasan et al., 2014). A report had been found for Ocimum basillicum, another species from Ocimum genus had shown significant inhibiting effects with aqueous extracts against sucrase and malatase due to the presence of phenolic compounds and flavonoid (El-Beshbishy and Bahashwan, 2012). This can further suggest that the aqueous extract of $O$. tenuiflorum had already been reported to have $\alpha$-amylase and $\alpha$-glucosidase inhibitory effects which are also carbohydrate hydrolyzing enzymes (Sudha et al., 2011; Rege and Chowdhary, 2014). So, it can be said that for sucrase, it had followed a similar pathway. Researchers also found that both the aqueous and ethanol extracts inhibited the enzyme more potently than acarbose (Rege and Chowdhary, 2014) which also partially relates with our study as both the aqueous extracts were able to show inhibition more than acarbose in the higher concentrations. There were a few studies that reported a significant amount of polyphenols present in water-alcohol fractions of $O$. tenuiflorum leaves (Wangcharoen and Morasuk, 2007) which is similar to our study but the inhibition percentages are less than the aqueous extracts. The possible reason for this phenomenon could be the presence of a lower amount of polyphenols in those extracts.

Our study showed the inhibition of AGEs by measuring the inhibition percentages of glycated BSA with both BSA-Glucose and fructose model. Most of the studies were done for non-enzymatic glycation followed an incubation period of 3-4 weeks with $37^{\circ} \mathrm{C}$ before addition of TCA (Adisakwattana et al., 2012; Ramkissoon et al., 2013; Adisakwattana et al., 2014) which made this assay a relatively time-consuming one. The increase of temperature can reduce this time such as increasing the incubation temperature to $60^{\circ} \mathrm{C}$ the incubation time reduced to 48 hours (Matsuura et al., 2002). In our experiments with both glucose and 
fructose, we followed an incubation period of $24 \mathrm{~h}$ at $60^{\circ}$ $\mathrm{C}$ which was able to form glycated BSA. Both two assays showed a higher amount of inhibition for glycated BSA for the aqueous extracts of oven-dried and fresh leaves, and the $50 \%$ ethanol extract of oven-dried leaves than the other samples. When it comes to the formation of AGEs, oxygen free radicals such as ROS plays an important part in the glycation of protein by lipid peroxidation. When these free radicals join the glycation process, they help in the formation of AGEs (Sabu and Kuttan, 2002). Thus, reducing the formation of these free radicals could possibly contribute to the inhibition of AGEs. Antioxidants such as polyphenols, flavonoids, saponins etc. had been known to reduce the number of free radicals as reported in several studies (Nikolova, 2011; Gupta et al., 2012). There are several plants with high antioxidant potential which has delivered a significant inhibition against the non-enzymatic glycation (Naowaboot et al., 2009; Ramkissoon et al., 2013). As reported earlier, aqueous extracts were found to be high in polyphenols and flavonoids, we can assume this to be the primary reason for its inhibition of glycated BSA. Some reports have suggested that sesquiterpenes and eugenol methyl ether had demonstrated antiglycation activities and these two are found in O. tenuiflorum. Thus, we can say they contribute to the leaves inhibition activity against glycated BSA (Singh et al., 2016; Hafizur et al., 2017). Another contributing factor could be the presence of saponin in hydro-alcoholic extracts of leaves of $O$. tenuiflorum (Devendran and Balasubramanian, 2011). Saponins had been reported to have antiglycation activity previously (Xi et al., 2008, Chen et al., 2011). A significant amount of saponin, eugenol and other phytochemical constituents which are responsible for antiglycation activity could have been present in the aqueous extracts also which justified our obtained results. There are not many studies conducted on the antiglycation potential of $O$. tenuiflorum plants. However, there were a few reports that suggested the potentiality of $O$. tenuiflorum having the antiglycation property. This indicates that plant phytochemical constituents are responsible for such activity (Mahomoodally et al., 2012; Tube et al., 2017).

\section{Conclusion}

Our present work evaluated the aqueous and ethanolic extracts of $O$. tenuiflorum leaves for its potential role to reduce diabetic complications by inhibiting sucrase and glycation of protein. The leaves had exerted a significant effect in its aqueous extracts and $50 \%$ ethanolic extracts. Some moderate inhibition activities were also observed for other extracts. As diabetic patients are increasing with time in the world, preliminary and secondary diabetic complication are causing chronic health issues among the patients. Various medicines are being used for treating these problems but that comes with some side effects which are unwanted. If the leaves of this plant could be used successfully and effectively, there are possibilities that reduction of diabetic complications can be achieved and possibly without side-effects.

\section{Conflicts of Interest}

We declare that we have no conflict of interest with this presented work.

\section{Acknowledgment}

The research has been financially supported by Research University (RU) with grant 1001/ PTEKIND/812176. We are thankful for their financial support towards the research.

\section{References}

Abdallah, H.M., Salama, M.M., Abd-Elrahman, E.H. and El-Maraghy, S.A. (2011). Antidiabetic activity of phenolic compounds from Pecan bark in streptozotocin-induced diabetic rats. Phytochemistry Letters, 4(3), 337-341. https://doi.org/10.1016/ j.phytol.2011.07.004

Adisakwattana, S., Sompong, W., Meeprom, A., Ngamukote, S. and Yibchok-anun, S. (2012). Cinnamic acid and its derivatives inhibit fructosemediated protein glycation. International Journal of Molecular Sciences, 13(2), 1778-1789. https:// doi.org/10.3390/ijms 13021778

Adisakwattana, S., Thilavech, T. and Chusak, C. (2014). Mesona Chinensis Benth extract prevents AGE formation and protein oxidation against fructoseinduced protein glycation in vitro. $B M C$ Complementary and Alternative Medicine, 14(1), 130. https://doi.org/10.1186/1472-6882-14-130

Ahmed, F., Chandra, J.N.N.S. and Timmaiah, N. (2009). An in vitro study on the inhibitory activities of Eugenia jambolana seeds against carbohydrate hydrolyzing enzymes. Journal of Young Pharmacists, 1, 317-321. https:// doi.org/10.4103/0975-1483.59320

Bailey, C.J. (2003). Future Drug Treatments of Type 2 Diabetes. In Holt, R.I.G., Cockram, C., Flyvbjerg, A. and Goldstein, B.J. (Eds) Textbook of diabetes. $5^{\text {th }}$ ed., p 1000-1011. UK: Wiley Blackwell

Bano, N., Ahmed, A., Tanveer, M., Khan, G.M. and Ansari, M.T. (2017). Pharmacological Evaluation of Ocimum sanctum. Journal of Bioequivalence and 
Bioavailability 9(3), 387-492.

Basu, A., Mitra, E., Mukherjee, D., Ghosh, A.K., Firdaus, S. B., Ghosh, D., Chattopadhyay, A., Pattari, S. K., Dutta, S., Jana, K. and Bandyopadhyay, D. (2013). Aqueous tulsi leaf (Ocimum sanctum 1.) extract protects against piroxicam-induced gastric ulceration in rats: involvement of antioxidant mechanisms. International Journal of Pharmacy and Pharmaceutical Sciences, 5(Suppl. 1), 438-447.

Brownlee, M. (2001). Biochemistry and molecular cell biology of diabetic complications. Nature, 414 (6865), 813-820. https://doi.org/10.1038/414813a

Cervantes-Laurean, D., Schramm, D.D., Jacobson, E.L., Halaweish, I., Bruckner, G.G. and Boissonneault, G. A. (2006). Inhibition of advanced glycation end product formation on collagen by rutin and its metabolites. The Journal of Nutritional Biochemistry, 17(8), 531-540. https:// doi.org/10.1016/j.jnutbio.2005.10.002

Chen, Y.F., Roan, H.Y., Lii, C.K., Huang, Y.C. and Wang, T.S. (2011). Relationship between antioxidant and antiglycation ability of saponins, polyphenols, and polysaccharides in Chinese herbal medicines used to treat diabetes. Journal of Medicinal Plants Research, 5(11), 2322-2331.

Deo, B., Nath, M., Nayak, P.K. and Dhal, Y. (2013). Evaluation of antioxidant activity of Ocimum tenuiflorum, an important medicinal herb. International Journal of Plant, Animal and Environmental Sciences 3(2), 150-154.

Derosa, G. and Maffioli, P. (2012). $\alpha$-Glucosidase inhibitors and their use in clinical practice. Archives of Medical Science (AMS), 8(5), 899-906. https:// doi.org/10.5114/aoms.2012.31621

Deve, A.S., Kumaresan, K. and Rapheal, V.S. (2014). Extraction process optimization of polyphenols from Indian Citrus sinensis-as novel antiglycative agents in the management of diabetes mellitus. Journal of Diabetes and Metabolic Disorders, 13(1), 11. https:// doi.org/10.1186/2251-6581-13-11

Devendran, G. and Balasubramanian, U. (2011). Qualitative phytochemical screening and GC-MS analysis of Ocimum sanctum L. leaves. Asian Journal of Plant Science and Research 1(4), 44-48.

El-Beshbishy, H.A. and Bahashwan, S.A. (2012). Hypoglycemic effect of basil (Ocimum basilicum) aqueous extract is mediated through inhibition of $\alpha$ glucosidase and $\alpha$-amylase activities: an in vitro study. Toxicology and Industrial Health, 28(1), 4250. https://doi.org/10.1177/0748233711403193

Gandhi, G.R., Ignacimuthu, S. and Paulraj, M.G. (2011).
Solanum torvum Swartz. fruit containing phenolic compounds shows antidiabetic and antioxidant effects in streptozotocin induced diabetic rats. Food and Chemical Toxicology, 49(11), 2725-2733. https://doi.org/10.1016/j.fct.2011.08.005

Gupta, M.N.S., Kumar, S.B., Duraiswamy, Chhajed, M. and Chhajed, A. (2012). In-vitro antioxidant and free radical scavenging activities of Ocimum sanctum. World Journal of Pharmaceutical Research, 1(1), 78 $-94$.

Hafizur, R.M., Momin, S. and Fatima, N. (2017). Prevention of advanced glycation end-products formation in diabetic rats through beta-cell modulation by Aegle marmelos. BMC Complementary and Alternative Medicine, 17(1), 227. https://doi.org/10.1186/s12906-017-1743-y

Hannan, J.M.A., Marenah, L., Ali, L., Rokeya, B., Flatt, P.R. and Abdel-Wahab, Y.H.A. (2006). Ocimum sanctum leaf extracts stimulate insulin secretion from perfused pancreas, isolated islets and clonal pancreatic $\beta$-cells. Journal of Endocrinology, 189(1), 127-136. https://doi.org/10.1677/joe.1.06615

He, K., Shi, J.C. and Mao, X.M. (2014). Safety and efficacy of acarbose in the treatment of diabetes in Chinese patients. Therapeutics and Clinical Risk Management, 10, 505-511

Hsieh, C.L., Peng, C.H., Chyau, C.C., Lin, Y.C., Wang, H.E. and Peng, R.Y. (2007). Low-density lipoprotein, collagen, and thrombin models reveal that Rosemarinus officinalis L. exhibits potent antiglycative effects. Journal of Agricultural and Food Chemistry, 55(8), 2884-2891. https:// doi.org/10.1021/jf0631833

Hu, X., Li, S., Wang, L., Zhu, D., Wang, Y., Li, Y., Yang, Y., Zhang, Z. and Cheng, D. (2013). AntiDiabetic Activities of Aqueous Extract from Actinidia kolomikta Root Against [alpha]glucosidase. Journal of Pharmacognosy and Phytochemistry, 2(4), 53-57.

Inampudi, S., Shaker, I.A. and Ratna, Y.K. (2010). Antioxidant activity and phenolic contents in Ocimum sanctum and Ocimum bascilicum. Asian Journal of Bio Science, 5(1), 1-5.

Kaewnarin, K. and Rakariyatham, N. (2017). Inhibitory Effects of Phenolic Compounds in Ocimum sanctum Extract on the $\alpha$-Glucosidase Activity and the Formation of Advanced Glycation Endproducts. Chiang Mai Journal of Science, 44(1), 203 -214 .

Kath, R.K. and Gupta, R.K. (2006). Antioxidant activity of hydroalcoholic leaf extract of Ocimum sanctum in animal models of peptic ulcer. Indian Journal of 
Physiology and Pharmacology, 50(4), 391-396

Li, W., Sun, Y.N., Yan, X.T., Yang, S.Y., Jo, S.H., Kwon, Y.I. and Kim, Y.H. (2014). Rat intestinal sucrase and-glucosidase inhibitory activities of isocoumarin and flavonoids from the Zanthoxylum schinifolium stems. Bulletin of the Korean Chemical Society, 35(1), 316-318. https://doi.org/10.5012/ bkcs.2014.35.1.316

Mahomoodally, F.M., Subratty, A.H., Gurib-Fakim, A. and Choudhary, M.I. (2012). Antioxidant, antiglycation and cytotoxicity evaluation of selected medicinal plants of the Mascarene Islands. $B M C$ Complementary and Alternative Medicine, 12(1), 165. https://doi.org/10.1186/1472-6882-12-165

Matsuura, N., Aradate, T., Sasaki, C., Kojima, H., Ohara, M., Hasegawa, J. and Ubukata, M. (2002). Screening system for the Maillard reaction inhibitor from natural product extracts. Journal of Health Science, 48(6), 520-526. https://doi.org/10.1248/ jhs. 48.520

Meenatchi, P., Purushothaman, A. and Maneemegalai, S. (2017). Antioxidant, antiglycation and insulinotrophic properties of Coccinia grandis (L.) in vitro: Possible role in prevention of diabetic complications. Journal of Traditional and Complementary Medicine, 7(1), 54-64. https:// doi.org/10.1016/j.jtcme.2016.01.002

Mohamed, E.A.H., Siddiqui, M.J.A., Ang, L.F., Sadikun, A., Chan, S.H., Tan, S.C., Asmawi, M.Z. and Yam, M.F. (2012). Potent $\alpha$-glucosidase and $\alpha$-amylase inhibitory activities of standardized 50\% ethanolic extracts and sinensetin from Orthosiphon stamineus Benth as anti-diabetic mechanism. BMC Complementary and Alternative Medicine, 12(1), 176. https://doi.org/10.1186/1472-6882-12-176

Mousavi, L., Salleh, R.M., Murugaiyah, V. and Asmawi, M.Z. (2016). Hypoglycemic and anti-hyperglycemic study of Ocimum tenuiflorum L. leaves extract in normal and streptozotocin-induced diabetic rats. Asian Pacific Journal of Tropical Biomedicine, 6(12), 1029-1036. https:// doi.org/10.1016/j.apjtb.2016.10.002

Nahak, G., Mishra, R.C. and Sahu, R.K. (2011). Phytochemical investigation and in vitro antioxidant evaluation of some Ocimum species. Journal of Pharmacy Research, 4(7), 2340-2343.

Naowaboot, J., Pannangpetch, P., Kukongviriyapan, V. and Kongyingyoes, B. (2009). Antihyperglycemic, antioxidant and antiglycation activities of mulberry leaf extract in streptozotocin-induced chronic diabetic rats. Plant Foods for Human Nutrition, 64 (2), 116-121. https://doi.org/10.1007/s11130-009$0112-5$
Nikolova, M. (2011). Screening of radical scavenging activity and polyphenol content of Bulgarian plant species. Pharmacognosy Research, 3(4), 256-259. https://doi.org/10.4103/0974-8490.89746

Pashikanti, S., de Alba, D.R., Boissonneault, G.A. and Cervantes-Laurean, D. (2010). Rutin metabolites: novel inhibitors of nonoxidative advanced glycation end products. Free Radical Biology and Medicine, 48(5), 656-663. https://doi.org/10.1016/ j.freeradbiomed.2009.11.019

Peng, X., Cheng, K.W., Ma, J., Chen, B., Ho, C.T., Lo, C., Chen, F. and Wang, M. (2008). Cinnamon bark proanthocyanidins as reactive carbonyl scavengers to prevent the formation of advanced glycation end products. Journal of Agricultural and Food Chemistry, 56(6), 1907-1911. https:// doi.org/10.1021/jf073065v

Peng, X., Zheng, Z., Cheng, K.W., Shan, F., Ren, G.X., Chen, F. and Wang, M. (2008). Inhibitory effect of mung bean extract and its constituents vitexin and isovitexin on the formation of advanced glycation end products. Food Chemistry, 106(2), 475-481. https://doi.org/10.1016/j.foodchem.2007.06.016

Perera, P.R.D., Ekanayake, S. and Ranaweera, K.K.D.S. (2014). Antiglycation and antioxidant activities of a ready to serve herbal drink of Syzygium cumini bark extract. Medical and Aromatic Plants, 3(148), 21670412.

Pripdeevech, P., Chumpolsri, W., Suttiarporn, P. and Wongpornchai, S. (2010). The chemical composition and antioxidant activities of basil from Thailand using retention indices and comprehensive twodimensional gas chromatography. Journal of the Serbian Chemical Society, 75(11), 1503-1513. https://doi.org/10.2298/JSC100203125P

Rabasa-Lhoret, R. and Chiasson, J.L. (2004). $\alpha$ Glucosidase Inhibitors. In DeFronzo, R.A., Ferraninni, E., Keen, H. and Zimmet, P. (Eds.) International textbook of diabetes mellitus. Vol. 1, p. 901-914. Chichester: John Wiley.

Ramkissoon, J.S., Mahomoodally, M.F., Ahmed, N. and Subratty, A.H. (2013). Antioxidant and antiglycation activities correlates with phenolic composition of tropical medicinal herbs. Asian Pacific Journal of Tropical Medicine, 6(7), 561-569. https://doi.org/10.1016/S1995-7645(13)60097-8

Rege, A.A. and Chowdhary, A. (2014). Evaluation of alpha-Amylase and alpha- Glucosidase inhibitory activities of Ocimum sanctum Linn. International Journal of Pharmaceutical Sciences Review and Research, 25(1), 130-133.

Sabu, M.C. and Kuttan, R. (2002). Anti-diabetic activity 
of medicinal plants and its relationship with their antioxidant property. Journal of Ethnopharmacology, 81(2), 155-160. https:// doi.org/10.1016/S0378-8741(02)00034-X

Shetty, S., Udupa, S. and Udupa, L. (2008). Evaluation of antioxidant and wound healing effects of alcoholic and aqueous extract of Ocimum sanctum Linn in rats. Evidence-Based Complementary and Alternative Medicine, 5(1), 95-101. https:// doi.org/10.1093/ecam/nem004

Singab, A.N., Youssef, F.S. and Ashour, M.L. (2014). Medicinal plants with potential antidiabetic activity and their assessment. Medicinal and Aromatic Plants, 3(1), 151.

Singh, P., Jayaramaiah, R.H., Agawane, S.B., Vannuruswamy, G., Korwar, A.M., Anand, A., Dhaygude, V.S., Shaikh, M.L., Joshi, R.S., Boppana, R. and Kulkarni, M.J. (2016). Potential dual role of eugenol in inhibiting advanced glycation end products in diabetes: proteomic and mechanistic insights. Scientific Reports, 6, 18798. https:// doi.org/10.1038/srep18798

Srinivasan, S., Sathish, G., Jayanthi, M., Muthukumaran, J., Muruganathan, U. and Ramachandran, V. (2014). Ameliorating effect of eugenol on hyperglycemia by attenuating the key enzymes of glucose metabolism in streptozotocin-induced diabetic rats. Molecular and Cellular Biochemistry, 385(1-2), 159-168. https://doi.org/10.1007/s11010-013-1824-2

Sudha, P., Zinjarde, S.S., Bhargava, S.Y. and Kumar, A.R. (2011). Potent $\alpha$-amylase inhibitory activity of Indian Ayurvedic medicinal plants. $B M C$ Complementary and Alternative Medicine, 11(1), 5. https://doi.org/10.1186/1472-6882-11-5

Tupe, R.S., Kemse, N.G., Khaire, A.A. and Shaikh, S.A. (2017). Attenuation of glycation-induced multiple protein modifications by Indian antidiabetic plant extracts. Pharmaceutical Biology, 55(1), 68-75. https://doi.org/10.1080/13880209.2016.1228683

Tupe, R.S., Kulkarni, A., Adeshara, K., Shaikh, S., Shah, N. and Jadhav, A. (2015). Syzygium jambolanum and Cephalandra indica homeopathic preparations inhibit albumin glycation and protect erythrocytes: an in vitro study. Homeopathy, 104(3), 197-204. https://doi.org/10.1016/j.homp.2015.02.009

Verma, S. (2016). Chemical constituents and pharmacological action of Ocimum sanctum (Indian holy basil-Tulsi). The Journal of Phytopharmacology, 5(5), 205-207.

Wangcharoen, W. and Morasuk, W. (2007). Antioxidant capacity and phenolic content of holy basil. Songklanakarin Journal of Science and
Technology, 29(5), 1407-1415.

Xi, M., Hai, C., Tang, H., Chen, M., Fang, K. and Liang, X. (2008). Antioxidant and antiglycation properties of total saponins extracted from traditional Chinese medicine used to treat diabetes mellitus. Phytotherapy Research, 22(2), 228-237. https://doi.org/10.1002/ptr.2297

You, Q., Chen, F., Wang, X., Jiang, Y. and Lin, S. (2012). Anti-diabetic activities of phenolic compounds in muscadine against alpha-glucosidase and pancreatic lipase. LWT-Food Science and Technology, 46(1), 164-168. https://doi.org/10.1016/ j.lwt.2011.10.011 